\title{
Analisis Kandungan Vitamin C Ekstrak Daun Kelor (Moringa oleifera Lam.) Pada Ketinggian Berbeda di Kota Baubau
}

\author{
Sarni $^{1}$, Hasty Hamzah ${ }^{2}$, Abdul Malik ${ }^{3}$, Ida Ifdaliah A. ${ }^{4}$, Khadijah ${ }^{5}$ \\ 1Program Studi Farmasi, Politeknik Baubau, Indonesia, Email: sarni_malik@yahoo.com \\ ${ }_{2}^{2}$ Program Studi Farmasi, Politeknik Baubau, Indonesia, Email: hastyhamzah@gmail.com \\ ${ }^{3}$ Program Studi Kebidanan, Politeknik Baubau, Indonesia, Email: olandoctora@gmail.com \\ ${ }^{4}$ Jurusan Teknik Kimia, Universitas Teknologi Sulawesi, Indonesia, Email: Idaifdaliah@gmail.com \\ 5 Program Studi Pendidikan Kimia, FPMIPA, Universitas Khairun, Indonesia, \\ Email:khadijah@unkhair.ac.id
}

Tanaman kelor merupakan salah satu tanaman yang banyak mengandung zat gizi baik itu mineral dan vitamin. Penelitian ini bertujuan untuk menentukan kandungan vitamin $C$ ekstrak daun kelor (Moringa oleifera Lam) dengan ketinggian berbeda di Kota Baubau. Daun kelor diekstraksi secara maserasi dengan menggunakan air dan Natrium Oksalat $\left(\mathrm{Na}_{2} \mathrm{C}_{2} \mathrm{O}_{4}\right)$ dan kadar vitamin $\mathrm{C}$ dianalisis menggunakan metode spektrofotometri UV-Vis. Hasil penelitian menunjukkan bahwa kadar vitamin $C$ daun kelor untuk ketinggian $20 \mathrm{mdpl}$ (KP 20) yang berada di daerah pesisir sebesar 0.59\%, 50 mdpl (KM 50) 0,53\%, sedangkan untuk ketinggian 296 mdpl (LBW) adalah $0,83 \%$. Dari data yang diperoleh menunjukkan bahwa kadar vitamin C paling tinggi adalah daun kelor yang terletak pada ketinggian 296 mdpl (LBW) dibandingkan dengan daerah dengan ketinggian yang rendah dalam hal ini kelor yang tumbuh di pesisir (KP 20) dan ketinggian menengah (KM 50). Dari hasil penelitian ini dapat disimpulkan bahwa kadar vitamin C ekstrak daun kelor yang tumbuh pada daerah rendah sebesar 296,40 ppm, ketinggian menengah 267,12 ppm dan untuk daerah ketinggian adalah 413,71 ppm.

Kata Kunci: daun Kelor, vitamin C, spekrofotometri UV-Vis

\begin{abstract}
Moringa plants are one of the plants that contain lots of nutrients both minerals and vitamins. This study aims to determine the content of Vitamin C extract of Moringa oleifera Lam extract with different heights in Baubau. Moringa leaves were extracted by maceration using water and Sodium Oxalate $\left(\mathrm{Na}_{2} \mathrm{C}_{2} \mathrm{O}_{4}\right)$ and vitamin $\mathrm{C}$ levels were analyzed using the UV-Vis Spectrophotometer Method. The results showed that the vitamin $C$ content of Moringa leaves for a height of 20 masl (KP 20) in the coastal area was 0.59\%, 50 masl (KM 50) 0.53\%, while for an altitude of 296 masl (LBW) was $0.83 \%$. From the data obtained shows that the highest levels of vitamin C are Moringa leaves located at a height of $296 \mathrm{mdl}(\mathrm{LBW})$ compared to areas with low altitude in this case Moringa that grows on the coast (KP 20) and medium height (KM 50). From the results of this study it can be concluded that the vitamin $\mathrm{C}$ content of Moringa leaf extract which grows in the low area is $296.40 \mathrm{ppm}$, medium height $267,12 \mathrm{ppm}$ and for the altitude region is $413.71 \mathrm{ppm}$.
\end{abstract}

Keywords: moringa oleifera Lam, vitamin C, spekrofotometri U-Vis 


\section{PENDAHULUAN}

Vitamin $C$ adalah salah satu vitamin yang dapat laut dalam air, vitamin $C$ dikenal juga dengan nama Asam askorbat, asam L-xiloaskorbat dan vitamin Antisorbutat. Vitamin C sangat mudah teroksidasi dalam bentuk cair menjadi asam dehidroaskorbat sehingga kadar vitamin C-nya berkurang dan gampang rusak (Mardalena, 2017). Vitamin C mempunyai banyak fungsi di dalam tubuh sehingga tubuh dapat melakukan proses metabolisme dan pertumbuhan yang normal. Vitamin C memainkan peran penting dalam homeostasis sel, bertindak sebagai antioksidan kuat serta modulator positif diferensiasi sel (Sandoval et al. 2013). Disamping itu Vitamin C dapat mengatasi salah satu masalah gizi utama yaitu Anemia gizi besi yang biasa dikenal dengan kurang darah. Penyebab anemia adalah disamping kurangnya jumlah zat besi di dalam tubuh, juga diakibatkan oleh zat besi yang kurang terserap atau teradsorbsi dengan baik (Citrakusumasari, 2012). Oleh karena itu, dengan adanya vitamin $\mathrm{C}$ dapat membantu penyerapan zat besi sehingga meningkatkan kadar hemoglobin dan menurunkan prevalensi anemia.

Vitamin $C$ tidak bisa diproduksi dan tidak dapat tersimpan lama dalam tubuh, sehingga untuk memenuhi kebutuhan tubuh akan vitamin $C$ maka harus mendapatkan asupan dari luar dan harus dikonsumsi tiap hari. Sumber vitamin $C$ di alam, selain dari buah buahan juga dapat diperoleh dari sayuran, salah satu sayuran yang memiliki kandungan vitamin $C$ yang tinggi adalah Daun kelor. Berdasarkan penelitian dalam 100 gram daun kelor mengandung vitamin $C$ yang setara dengan 7 kali kandungan vitamin $C$ yang ada pada buah jeruk (Mahmood, Mugal, and Haq 2010), bahkan beberapa literatur dijelaskan kelor mempunyai kadar protein 3 kali dari protein telur, 25 kali zat besi dan vitamin C bayam, 12 kali kalsium serta 2 kali protein susu (Diantoro et al. 2015). Penelitian Cahyati, dkk (2016) menunjukkan kandungan vitamin $C$ dalam 100 gram daun kelor tua di pesisir sebesar 363,49 mg dan di daerah pegunungan 312,05 mg. Tahir dkk (2015) juga melaporkan kandungan vitamin C daun kelor sebesar $7,96 \mathrm{mg} / \mathrm{g}$.

Tanaman kelor (Moringa oleifera) merupakan tanaman perdu dengan ketinggian 7-11 meter dan tumbuh subur mulai dari dataran rendah sampai ketinggian $700 \mathrm{~m}$ di atas permukaan laut. Kelor dapat tumbuh pada daerah tropis dan subtropis pada semua jenis tanah dan tahan terhadap musim kering dengan toleransi terhadap kekeringan sampai 6 bulan (Mendieta et al., 2013). Tanaman kelor memiliki bunga berwarna putih kekuning kuningan dan tudung pelepah bunganya berwarna hujau. Bunga kelor keluar sepanjang tahun dengan aroma bau semerbak. Buah kelor berbentuk segitiga memanjang yang disebut klentang (Jawa). Buahnya keras dan berukuran panjang $120 \mathrm{~cm}$ (Luthfiyah, F., 2012).

Tanaman Kelor digambarkan dunia sebagai tanaman yang paling bergizi dan mengandung banyak nutrisi, memiliki khasiat dan banyak manfaatnya sehingga menjadikan kelor mendapat julukan sebagai Mother's Best Frienly dan Miracle Tree. Tanaman ini mudah tumbuh dan ditemukan diseluruh wilayah Indonesia khususnya di daerah pedesaan, namun belum dimanfaatkan secara maksimal dalam kehidupan, pada umumnya hanya dijadikan pagar dan sebagai salah satu jenis sayuran (Aminah, Ramdhan, and Yanis 2015). Daun kelor mengandung berbagai zat kimia yang bermanfaat sebagai bahan obat-obatan berkhasiat untuk kesehatan karena mengandung flavonoid sebagai antioksidan dan antiinflamasi (Kurniawan, 2017). Daun kelor dapat digunakan sebagai antioksidan alami dengan mencegah kerusakan yang ditimbulkan oleh radikal bebas dengan nilai $\mathrm{IC}_{50}$ berkisar 5,72-42,56 $\mu \mathrm{g} / \mathrm{mL}$ 
(Unuigbe et al, 2014). Antioksidan alami tersebut berupa vitamin C, tokoferol (vitamin E), betakaroten, dan antioksidan fitokimia dari golongan fenolik (Ikhlas, 2013). Uji fitokimia daun kelor menunjukkan positif terhadap kandungan antioksidan alami seperti flavonoid, alkaloid, saponin, tannin dan karatenoid (Nweze and Nwafor, 2014), juga mengandung steroid, triterpenoid, saponin, antraquinon, serta mengandung mineral, asam amino esensial, dan berbagai vitamin (Krisnandi, 2013; Hardiyanthi, 2015). Oleh karena itu, tanaman kelor juga dapat digunakan sebagai tanaman obat berkhasiat, namun bukan hanya daun yang bisa dimanfaatkan juga seluruh bagian tanaman termasuk kulit batang, biji, buah dan akarnya (Fajri, Rahmatu, and Alam , 2018).

Untuk masyarakat Baubau Sulawesi Tenggara, daun kelor bukanlah hal yang baru, hampir di setiap pekarangan rumah terdapat tumbuhan kelor. Selain digunakan sebagai sayur, daun kelor juga dimanfaatkan sebagai obat tradisional alami. Beberapa contoh pemanfaatan daun kelor sebagai obat oleh masyarakat lokal antara lain untuk menghentikan pendarahan atau luka, menghilangkan racun atau mabuk karena minuman alkohol, dan juga dapat digunakan sebagai penghilang bau amis pada ikan. Pemanfaatan daun kelor ini telah dikenal oleh masyarakat Baubau jauh sebelum adanya penelitian tentang daun kelor. Baubau merupakan daerah yang memiliki topografi dengan ketinggian dan kondisi tanah yang berbeda-beda. Pada beberapa jenis buah dan sayuran termasuk tanaman kelor, kondisi lingkungan dimana tempat tumbuh, dapat mempengaruhi terjadinya perubahan morfologi dan kandungan senyawa metabolitnya. Salah satu kondisi lingkungan yang dimaksud adalah perbedaan atau perubahan ketinggian dimana tanaman tersebut tumbuh (Magfiroh, 2017; Mardalena, 2017). Perbedaan regional atau lokasi tumbuh daun kelor dapat berpengaruh terhadap kuantitas kandungan nutrisinya, termasuk kandungan vitamin C-nya. Semakin tinggi ketinggian tempatnya, maka semakin tinggi pula stress lingkungan. Ketika tanaman mengalami stress, maka produksi metabolit sekunder termasuk produksi vitamin mengalami peningkatan (Fatchurrozak 2013). Hal ini merujuk pada penelitian yang telah dilakukan oleh Fajri, dkk (2018), bahwa ketinggian tempat tumbuh tanaman kelor sangat berpengaruh nyata terhadap kandungan klorofil, vitamin $\mathrm{C}$ dan serat.

Meskipun telah banyak penelitian sebelumnya tentang kandungan vitamin $C$ pada kelor, namun setiap daerah memiliki kondisi lingkungan yang berbeda-beda sehingga mempengaruhi kandungan metabolit sekunder yang ada di dalamnya termasuk kandungan vitamin C. Analisis kandungan vitamin C pada sayuran dan buah dapat ditentukan dengan beberapa metode, salah satunya adalah metode spektrofotometri UV-Vis. Metode spektrofotometri UV- Vis dapat digunakan untuk analisis kualitatif maupun kuantitatif. Berdasarkan uraian latar belakang, kami tertarik untuk menganalisis kandungan vitamin C ekstrak daun kelor pada beberapa tempat dengan ketinggian yang berbeda di Kota Baubau.

\section{METODE PENELITIAN}

Metode penelitian yang digunakan pada peneltian ini mengacu pada metode penelitian yang biasa dilakukan untuk mengisolasi senyawa organik bahan alam khususnya dari tumbuhan, antara lain penentuan tempat, persiapan dan pengambilan sampel, pengolahan sampel yang meliputi ekstraksi dan analisis kadar vitamin C menggunakan metode spektrofotomeri UVVis. Penelitian ini dilakukan pada bulan Juli hingga Agustus 2019 di Laboratorium Biokimia Jurusan Kimia Fakultas MIPA Universitas Hasanuddin, Makassar. 
Alat yang digunakan dalam penelitian meliputi; Neraca Analitis Thermo, Mikro pipet, pipet volume, vortex, sentrifuge dingin Universal $320 \mathrm{R}$, spektrofotometer UV-2600 Shimadzu, Blender Miyako BL 152 GF, Alat-alat gelas. Sementara bahan yang digunakan dalam penelitian terdiri dari; Daun kelor, $\mathrm{Na}_{2} \mathrm{C}_{2} \mathrm{O}_{4}, \mathrm{C}_{6} \mathrm{H}_{8} \mathrm{O}_{7} . \mathrm{H}_{2} \mathrm{O}, \mathrm{Na}_{2} \mathrm{HPO}_{4} .2 \mathrm{H}_{2} \mathrm{O}$ p.a, vitamin $\mathrm{C}$, kertas saring, aluminium foil, dan akuades saring, aluminium foil, dan akuades.

\section{Prosedur Penelitian}

Dalam penelitian ini prosedur kerja untuk analisis vitamin C pada ekstrak daun kelor merujuk pada Cahyati R.D., dkk (2016), dimana daun kelor diekstraksi secara maserasi dengan menggunakan air dan Natrium Oksalat $\left(\mathrm{Na}_{2} \mathrm{C}_{2} \mathrm{O}_{4}\right)$ dan kadar vitamin $\mathrm{C}$ dianalisis menggunakan metode Spektrofotometri UV-Vis.

\section{Pembuatan Larutan Buffer Fosfat Sitrat pH 5}

Sebanyak 121,25 mL asam sitrat $\left(\mathrm{C}_{6} \mathrm{H}_{8} \mathrm{O}_{7} \cdot \mathrm{H}_{2} \mathrm{O} 0,1 \mathrm{M}\right)$ dan $128,75 \mathrm{~mL} \mathrm{Na} \mathrm{HPO}_{4} .2 \mathrm{H}_{2} \mathrm{O}$ 0,2 M dicampurkan ke dalam labu ukur $250 \mathrm{~mL}$, selanjutnya dihomogenkan.

\section{Pembuatan Larutan Natrium Oksalat 0,01 N}

Padatan $\mathrm{Na}_{2} \mathrm{C}_{2} \mathrm{O}_{4}$ ditimbang sebanyak 0,1675 gram kemudian dilarutkan dengan buffer fosfat sitrat pH 5. Larutan dimasukkan ke dalam labu ukur $250 \mathrm{~mL}$, dihimpitkan hingga tanda batas dan dihomogenkan.

\section{Pembuatan Larutan Induk Vitamin C 1000 ppm}

Vitamin $\mathrm{C}$ sebanyak 0,05 gram dimasukkan ke dalam gelas kimia $50 \mathrm{~mL}$ kemudian dilarutkan dengan $\mathrm{Na}_{2} \mathrm{C}_{2} \mathrm{O}_{4}$ 0,01 N. Selanjutnya larutan dimasukkan ke dalam labu ukur $50 \mathrm{~mL}$ dan dihimpitkan hingga tanda batas dan dihomogenkan.

\section{Pembuatan Larutan Vitamin C 500 ppm}

Larutan induk vitamin C 1000 ppm dipipet 12,5 mL kemudian dimasukkan ke dalam labu ukur $25 \mathrm{~mL}$, kemudian dihimpitkan dengan $\mathrm{Na}_{2} \mathrm{C}_{2} \mathrm{O}_{4} 0,01 \mathrm{~N}$ hingga tanda batas dan dihomogenkan.

\section{Pembuatan Larutan Standar Asam Askorbat 2 ppm; 4 ppm; 8 ppm; 16 ppm; dan $32 \mathrm{ppm}$}

Larutan vitamin C 500 ppm dipipet secara berturut-turut masing-masing sebanyak $0,04 \mathrm{~mL}$; 0,08 mL; 0,16 mL; 0,32 mL dan 0,64 mL, kemudian dimasukkan ke dalam labu ukur $10 \mathrm{~mL}$. Selanjutnya dihimpitkan dengan larutan $\mathrm{Na}_{2} \mathrm{C}_{2} \mathrm{O}_{4} \quad 0,01 \mathrm{~N}$ hingga tanda batas dan dihomogenkan setelah itu diukur absorbansinya dengan spektrofotometer UV-Vis pada panjang gelombang maksimum. Selanjutnya dibuat kurva kalibrasi antara konsentrasi $(x)$ dan absorbansi (y) sehingga diperoleh persamaan garis lurus.

\section{Penentuan Kandungan vitamin C dengan Spektrofotometer UV-Vis}

Sampel daun kelor dibersihkan dan dihaluskan, selanjutnya diambil yang mewakili keseluruhan sampel lalu ditimbang sebanyak 1 gram. Kemudian masing-masing sampel diekstraksi dengan $4 \mathrm{~mL}$ larutan $\mathrm{Na}_{2} \mathrm{C}_{2} \mathrm{O}_{4} 0,01 \mathrm{~N}$, kemudian disentrifuge, larutan didekantasi dan dipisahkan. Proses sentrifuge diulang hingga residu sampel menjadi tidak berwarna. Filtrat sampel yang telah dipisahkan kemudian diukur absorbansinya dengan spektrofotometer UV-Vis pada panjang gelombang maksimum. 


\section{HASIL DAN PEMBAHASAN}

Pada penelitian ini, dilakukan pengukuran kadar Vitamin C ekstrak daun kelor (Moringa oleifera) menggunakan metode Spektrofotometer UV-Vis. Sampel daun kelor pada penelitian ini berasal dari daerah dengan ketinggian 20 mdpl berada di daerah pesisir, ketinggian 50 mdpl dan pada ketinggian 296 mdpl yang berada di daerah pegunungan kota Baubau. Pohon kelor yang dipilih sebagai sampel rata-rata berumur 10 sampai 15 tahun dengan usia pemanenan sekitar 2 bulan dan daun yang digunakan sebagai sampel adalah campuran daun kelor tua dan agak tua.

Tabel 1. Hasil pengukuran absorbansi larutan standar vitamin C

\begin{tabular}{cc}
\hline Larutan Standar Vitamin C (ppm) & $\begin{array}{c}\text { Absorbansi } \\
(\mathrm{A})\end{array}$ \\
\hline 2 & 0,6890 \\
\hline 4 & 0,08830 \\
\hline 8 & 1,3200 \\
\hline 32 & 2,3830 \\
\hline
\end{tabular}

Dari data pengukuran larutan standar vitamin C (Tabel 1), maka diperoleh serapan yang membentuk kurva kalibrasi pada rentang konsentrasi 2 ppm, 4 ppm, 8 ppm, 16 ppm dan 32 ppm pada panjang gelombang 262,5 nm. Dari hasil pengukuran menunjukkan adanya hubungan linier antar konsentrasi dan absorbansi, yang dapat digambarkan dalam bentuk persamaan regresi linier $y=0,095 x+0,572$, dengan koefisien korelasi 0,980 . Oleh karena itu, persamaan regresi ini dapat digunakan untuk menghitung kadar vitamin $C$ dalam ekstrak daun kelor.

Tabel 2. Data absorbansi dan kadar vitamin C sampel kelor

\begin{tabular}{cccc}
\hline Kode sampel & Absorbansi & Vit. C terukur $(\mathrm{ppm})$ & Vit. C terukur (\%) \\
\hline KP 20 & 3.397 & 296.40 & 0.59 \\
\hline KM 50 & 3.118 & 267.12 & 0.53 \\
\hline LBW & 4.515 & 413.71 & 0.83 \\
\hline
\end{tabular}

Keterangan:

KP 20 = Kelor pesisir $20 \mathrm{mdpl}$

KM 50 = Kelor Menengah $50 \mathrm{mdpl}$

LBW = Kelor daerah ketinggian Kel. Labalawa 296 mdpl

Kadar vitamin $\mathrm{C}$ pada masing-masing sampel diperoleh dengan cara mengkonversi data absorbansi (y) ke dalam bentuk konsentrasi (ppm) dari persamaan regresi yang diperoleh dari kurva kalibrasi larutan standar vitamin C. konsentrasi atau kadar (ppm) sebagai nilai (x) diubah dalam satuan persen (\%) dengan menggunakan teknik pengolahan data, sehingga diperoleh kadar vitamin C kelor untuk KP 20 sebesar 0.59\%, KM 50 0,53\%, sedangkan untuk LBW adalah $0,83 \%$. Dari data yang diperoleh menunjukkan bahwa kadar vitamin C paling tinggi adalah daun kelor yang terletak pada ketinggian 296 mdpl (LBW) dibandingkan dengan daerah dengan ketinggian yang rendah, dalam hal ini kelor yang tumbuh di pesisir 
KP 20 dan ketinggian menengah KM 50. Hasil ini berbanding terbalik dengan beberapa penelitian seperti yang dilakukan oleh Cahyati, dkk (2016) dan Fajri, dkk (2018), yang memperoleh hasil bahwa kadar vitamin $C$ daun kelor lebih tinggi diperoleh pada wilayah dengan ketinggian yang rendah atau daerah pesisir. Hasty, dkk (2019) juga telah meneliti hubungan variasi ketinggian tempat dengan kadar Fe dalam daun kelor yang tumbuh di Kota Baubau dan hasil penelitiannya menunjukkan kadar zat besi (Fe) daun kelor tertinggi berada di daerah pesisir. Sebaliknya hasil penelitian ini sejalan dengan hasil penelitian Fatchurrozak (2013) yang menguji pengaruh ketinggian tempat terhadap kandungan vitamin $\mathrm{C}$ buah Carica pubescens dan diperoleh kadar vitamin $\mathrm{C}$ yang lebih tinggi pada dataran tinggi.

Perbedaan kadar vitamin $\mathrm{C}$ yang diperoleh dipengaruhi oleh lingkungan dimana tumbuhan tersebut tumbuh. Pengaruh ketinggian tempat terutama berkaitan dengan proses metabolisme tanaman, seperti proses biokimia dan sintesis senyawa metabolit sekunder, seperti vitamin (Karamoy, 2009). Hal tersebut akan mempengaruhi pertumbuhan, karakter morfologi, maupun kandungan senyawa aktif pada suatu tanaman. Semakin tinggi ketinggian tempatnya, maka semakin tinggi pula stres lingkungan, misalnya suhu semakin rendah, kelembaban semakin tinggi, intensitas cahaya matahari semakin kecil, lama penyinaran semakin singkat. Stres suhu, cahaya, kelembaban, dan lain-lain dapat mempengaruhi produksi metabolit sekunder tanaman. Semakin tinggi stres lingkungan maka kandungan metabolit sekunder suatu tanaman semakin meningkat, termasuk produksi vitamin yang ada di dalamnya, begitu juga dengan kadar vitamin $C$ daun kelor yang diperoleh pada penelitian ini. Semakin rendah ketinggian tempat, intensitas sinar matahari dan temperatur semakin tinggi, maka vitamin $\mathrm{C}$ semakin mudah teroksidasi membentuk asam dehidroaskorbat. Sehingga menyebabkan rendahnya kadar vitamin $C$ pada daerah dataran rendah.

\section{KESIMPULAN}

Dari hasil penelitian ini dapat disimpulkan bahwa kadar vitamin C ekstrak daun kelor yang tumbuh pada daerah rendah sebesar 296,40 ppm, ketinggian menengah 267,12 ppm dan untuk daerah ketinggian (pegunungan) adalah 413,71 ppm.

\section{UCAPAN TERIMAKASIH}

Terima kasih kepada Kementerian Riset Teknologi dan Pendidikan Tinggi yang telah membiayai penelitian ini melalui program hibah penelitian PDP 2018.

\section{DAFTAR PUSTAKA}

Aminah, Syarifah, Tezar Ramdhan, and Muflihani Yanis. 2015. 'Kandungan Nutrisi Dan Sifat Fungsional Tanaman Kelor (Moringa oleifera)'. Buletin Pertanian Perkotaan 5 Nomor 2.

Citrakusumasari. 2012. Anemia Gizi, Dan Masalah Pencegahannya. Yogyakarta: Kalika.

Diantoro, Agung, Muzaki Rohman, Ratna Budiarti, and Hapsari Titi Palupi. 2015. ‘Pengaruh Penambahan Ekstrak Daun Kelor (Moringa oleifera L.) Terhadap Kualitas Yoghurt'. Jurnal Teknologi Pangan.

Fajri, Rostiati Rahmatu, and Nur Alam. 2018. 'Kadar Klorofil Dan Vitamin C Daun Kelor (Moringa oleifera Lam) Dari Berbagai Ketinggian Tempat Tumbuh'. E-J. Agrotekbis 6 (2): 152-158. 
Fatchurrozak, Fatchurrozak. 2013. ‘Pengaruh Ketinggian Tempat Terhadap Kandungan Vitamin C dan Zat Antioksidan Pada Buah Carica pubescens Di Dataran Tinggi Dieng'. EL- VIVO 1 No. 1. http://jurnal.pasca.uns.ac.id/index.php/elv/article/view/652.

Hardiyanthi, F. 2015. ‘Pemanfaatan Aktivitas Antioksidan Ekstrak Daun Kelor (Moringa oleifera) Dalam Sediaan Hand and Body Cream'. Jakarta: UIN Syarif Hidayatullah.

Hamzah, H. \& Yusuf, N.R., 2019. Analisis Kandungan Zat besi (Fe) Pada Daun Kelor (Moringa oleifera Lam.) Yang Tumbuh dengan Ketinggian Berbeda di Daerah Kota Baubau. Indo. J. Chem. Res., 2019, 6.2: 88-93

Ikhlas, N. 2013. ‘Uji Aktivitas Antioksidan Ekstrak Herba Kemangi (Ocimum americanum Linn) Dengan Metode DPPH (2,2-Dofenil-1-Pikrilhidrazil)'. Jakarta: UIN Syarif Hidayatullah.

Karamoy, Lientje. 2009. 'Hubungan Iklim Dengan Pertumbuhan Kedelai'. Soil Environment 7 (1) : 65-68.

Krisnandi, A.D. 2013. Kelor Super Nutrisi. Kunduran, Jawa Tengah: Pusat Informasi dan Pengembangan Tanaman Kelor Indonesia (LSM-MEPELING).

Kurniawan, Kiki Wahyu. 2017. ‘Aktivitas Antioksidan Dan Organoleptik Teh Daun Kelor Kombinasi Daun Jambu Biji Dengan Variasi Suhu Pengeringan Serta Penambahan Jahe'. Surakarta: Universitas Muhamadiyah Surakarta.

Luthfiyah, F. 2012. 'Potensi Gizi Daun Kelor (Moringa oliefera) Nusa Tenggara Barat'. Media Bina Ilmiah 6 No.2.

Magfiroh, Umi Laelatul. 2017. ‘Faktor Ketinggian Tempat Terhadap Sintesis Vitamin Buah Carica (Carica pubecens)'. Prosiding Seminar Nasional Pendidikan Biologi Dan Biologi, 69-74.

Mahmood, K.T., T. Mugal, and I.U. Haq. 2010. 'Moringa oleifera: A Natural Gift-a Review'. Journal of Pharmaceutical Sciences and Research 2 (November): 775-81.

Mardalena, Ida. 2017. Dasar-Dasar Ilmu Gizi Dalam Keperawatan: Konsep Dan Penerapan Pada Asuhan Keperawatan. Yogyakarta: Pustaka Baru Press.

Mendieta, Araica, E Sporndly, Sanchez Reyes, Miranda Salmeron, and M Halling. 2013. 'Biomass Production and Chemical Composition of Moringa oleifera under Different Planting Densities and Level of Nitrogen Fertilization'. Agroforest. Syst. 87: 81-92.

Nweze, Nkechinyere O., and Felix I. Nwafor. 2014. 'Phytochemical, Proximate and Mineral Composition of Leaf Extracts of Moringa oleifera Lam. From Nsukka, South-Eastern Nigeria'. Journal of Pharmacy and Biological Sciences Vol. 9 no.1.

Sandoval, Daniel, Jorge Ojeda, Marcela Low, Francisco Nualart, Sylvain Marcellini, Nelson Osses, and Juan Pablo Henríquez. 2013. 'The Vitamin C Transporter SVCT2 Is Down-Regulated during Postnatal Development of Slow Skeletal Muscles'. Histochem Cell Biol 139 (6) : 887-894. https://doi.org/10.1007/s00418-012-1075-4.

Tahir, M., Hikmah, N., Rahmawati, 2015, Analisis Kandungan Vitamin C dan $\beta$ Karoten Dalam Daun Kelor (Moringa oleifera Lam) Dengan Metode Spektrofotometri UV-VIS. Jurnal Fitofarmaka Indonesia vol. 3 No.1.

Unuigbe, Charles A, Henry A. Okeri, Osayemwenre Erharuyi, Emmanuel E. Oghenero, and Dominic A. Obamedo. 2014. 'Phytochemical and Antioxidant Evaluation of Moringa oleifera (Moringaceae) Leaf and Seed'. Journal of Pharmacy and Bioresources Vol. 11 no. 2: 51-57. 